\title{
Implikasi Pengelolaan Pembelajaran Bermutu Pada Kelas Unggulan
}

\author{
Suresmi \\ Universitas Islam Negeri Raden Intan Lampung \\ suresmi2020@gmail.com
}

\begin{abstract}
The existence of a superior class in madrasah is an institution that is specifically designed and developed systematically, adequate facilities/infrastructure, curriculum, qualified teaching and education staff, and so on. The existence of a superior class can increase the competitiveness of madrasas and the bargaining position of madrasas as superior madrasas will be even stronger. To increase the competitiveness of these madrasas as superior madrasas, it is necessary to properly manage quality learning. This article discusses planning, organizing, implementing, evaluating and the implications of quality learning in superior classes at MTsN 2 Bandar Lampung and at MTsN 2 Tanggamus. This research is a field research, using a qualitative approach with a multisite study design. Data collection techniques using in-depth interviews, observation and documentation. Descriptive data analysis techniques with the Analysis Interactive Model. The results of the study, learning in superior classes at MTsN 2 Model Bandar Lampung and MTsN Model Talang Padang are designed through planning, organizing, implementing, and evaluating middle input through superior processes based on the spirit of spiritual learning that can strengthen the learning system. The implications of managing quality learning in superior classes at MTsN 2 Bandar Lampung and at MTsN 2 Tanggamus are: The establishment of an integrated learning system and the establishment of teacher standardization.
\end{abstract}

Keywords: Implication, management, quality learning, superior class

\begin{abstract}
Abstrak: Keberadaan Kelas unggulan pada madrasah merupakan sebuah lembaga yang didesain secara khusus dan dikembangkan secara sistematis, sarana/prasarana yang memadai, kurikulum, tenaga pendidik dan kependidikan yang berkualifikasi, dan lain sebagainya. Keberadaan kelas unggulan dapat meningkatkan daya saing madrasah serta posisi tawar madrasah sebagai madrasah unggul akan semakin kuat. Untuk meningkatkan daya saing madrasah tersebut sebagai madrasah yang unggul diperlukan pengelolaan pembelajaran bermutu dengan yang benar. Artikel ini membahas mengenai perencanaaan, pengorganisasian, pelaksanaan, evaluasi serta implikasi pembelajaran bermutu pada kelas unggulan di MTsN 2 Bandar Lampung dan di MTsN 2 Tanggamus. Penelitian ini merupakan penilitian lapangan, dengan menggunakan pendekatan kualitatif dengan rancangan studi multisitus. Teknik pengumpulan data menggunakan teknik wawancara mendalam, observasi dan dokumentasi. Teknik analisis data deskriptif dengan Analysis Interactive Model. Hasil penelitian, Pembelajaran pada kelas unggulan di MTsN 2 Model Bandar Lampung dan MTsN model Talang Padang didesain melalui perencanaan, pengorganisasian, pelaksanaan, dan evaluasi terhadap input yang middle melalui proses yang unggul dengan dilandasi oleh semangat spritual learning yang dapat memperkuat sistem pembelajaran. Implikasi pengelolaan pembelajaran bermutu pada kelas unggulan di MTsN 2 Bandar Lampung dan di MTsN 2 Tanggamus telah yaitu: Terbentuknya sistem pembelajaran yang integratif dan Terbentuknya standarisasi guru.
\end{abstract}

Kata Kunci: Implikasi, Pengelolaan, Pembelajaran Bermutu, Kelas Unggulan 


\section{PENDAHULUAN}

Pendidikan pada hakikatnya adalah usaha sadar yang dilakukan untuk memanusiakan manusia. Pendidikan merupakan sarana yang sangat strategis dalam melestarikan sistem nilai yang berkembang dalam masyarakat. Hal ini sejalan dengan pendapat Ondi Saondi dan Aris Suherman, yang mengatakan bahwa pendidikan adalah usaha sadar dan terencana untuk mewujudkan proses pembelajaran yang aktif, inovatif, kreatif, efektif dan menyenangkan agar peserta didik secara aktif mampu mengembangkan potensi dirinya untuk menguasai Ilmu Pengetahuan dan Teknologi (IPTEK), memiliki nilai keagamaan, pengendalian diri, kepribadian, kecerdasan, akhlak mulia, serta keterampilan yang diperlukan dirinya dan masyarakat. (Ondi Saondi dan Aris Suherman, 2010) Untuk dapat melaksanakan pendidikan sesuai harapan tersebut maka dibutuhkan pendidikan bermutu yang dapat mengembangkan segenap potensi peserta didik.

Madrasah merupakan lembaga formal yang diperuntukkan sebagai tempat untuk mengembangkan keilmuan (ilmu umum dan khususnya keagamaan), proses pembelajaran terintegrasi dalam sistem pendidikan nasional. Madrasah sebagai sekolah berciri khas keagamaan (Islam) diartikan sebagai keseluruhan kegiatan kependidikan yang keberadaan dan historisnya memiliki ciri dan karakter yang diwarnai oleh nilai-nilai ke-Islaman. Kekhasan tersebut menjadikan pengelolaan madrasah harus dapat memberikan landasan Islam yang kokoh agar peserta didik memiliki kepribadian yang kuat yang dilandasi oleh nilai-nilai ke-Islaman bagi perkembangan kehidupannya serta menjadi manusia Indonesia seutuhnya yang berani bersaing dalam menghadapi era global.

Seiring dengan era reformasi yang menghasilkan paradigma baru dalam sistem pendidikan nasional. Madrasah semakin ditantang untuk mampu mempertahankan keberadaan dan perjalanan pengabdian bagi bangsa Indonesia. Potret pengelolaan pendidikan madrasah sebagai bagian dari sub sistem pendidikan, pengelolaan pendidikan masih bermuara pada seputar rutinitas kegiatan pembelajaran dengan capaian target-target jangka pendek, namun masih kurang bertumpu pada kebutuhan subtantif peserta didik dengan melihat kebutuhan jangka panjangnya.

Pengadaan kelas unggulan utamanya dalam hal ini adalah pada setiap jenjang pendidikan menengah formal, begitu juga MTsN 2 Bandar Lampung dan MTsN 2 Tanggamus. Alasannya adalah Madrasah Tsanawiyah sebagai lembaga pendidikan menengah formal memiliki kesempatan yang sama dengan kelas menengah umum dalam penyelenggaraan program kelas unggulan (Harun, 2016). Dalam perundang-undangan tentang pendidikan tidak membeda-bedakan sistem pendidikan yang diselenggarakan oleh kelas umum dan madrasah. Nomenklatur madrasah selalu digandengkan dengan kelas umum pada tiap-tiap 
jenjangnya. Alasan lainnya adalah bahwa jenjang pendidikan ini mendekati jenjang pendidikan tinggi. Tentunya dibutuhkan kesiapan lebih bagi peserta didik mengikuti pendidikan pada jenjang pendidikan tinggi.

Pengelolaan pendidikan dengan capaian jangka pendek misalnya, sangat nampak dan sekaligus menjadi fenomena menarik di sekolah maupun madrasah manapun, fenomena yang dimaksud antara lain, peserta didik dapat naik kelas, dapat lulus Ujian Nasional dan berhenti sampai di situ, padahal sesungguhnya tidak hanya dituntut sekedar naik kelas, lulus ujian dan mendapat nilai tinggi, melainkan bagaimana peserta didik memiliki karakter pembelajaran, memiliki kepekaan terhadap kebutuhannya, dan bertanggung jawab pada dirinya sebagai komunitas pelajar. Inilah yang dimaksud dengan kebutuhan subtantif peserta didik untuk capaian jangka panjangnya (Ahyar, 2018). Madrasah sebagai institusi yang diberi amanah, tentunya dihadapkan dengan tantangan yang demikian kompleks, tidak hanya datang dari internal namun juga datang dari eksternal madrasah.

Tantangan yang bersifat internal misalnya, manajemen kelembagaan, tenaga kependidikan, kurikulum, strategi pembelajaran, kualitas lulusan, dana (Agus Maimun dan Agus Zaenal Fitri, 2010), program pembinaan, kekurangan sekolah membangun team work yang solid dalam membangun dan mengelola pembelajaran, ketiadakmampuan membangun hubungan antar personal yang kokoh, ketidakstabilan iklim kerja, kekurangmampuan dalam memonitor proses pembelajaran. Sementara tantangan eskternalnya, ketiadakmampuan madrasah membangun sinergi dengan berbagai pihak, resisten terhadap perubahan, ketidakmampuan menyesuaikan diri dengan tuntutan perubahan sosial, perkembangan teknologi pembelajaran dan masih banyak lagi tantangan lainnya.

Adanya tantangan-tantangan internal dan eksternal madrasah di atas, tidaklah mudah diurai menjadi kekuatan dan diolah menjadi peluang untuk maju. Kendati demikian, madrasah tidak boleh latah dengan keadaan yang ada, madrasah diharapkan menjadi pelopor perubahan dan inovator dengan segala potensi yang dimilikinya. Sebagai pelopor inovasi misalnya, dapat ditelaah dari beberapa hasil riset. Hasil riset yang dimaksud adalah kajian tentang inovasi lingkungan pembelajaran. Inovasi lingkungan pembelajaran mengetengahkan bahwa dalam mereform agenda sekolah atau madrasah dapat dibangun melalui tiga pilar utama, pertama; riset atas pembelajaran dan pengajaran, kedua; mempertimbangkan pengalaman inovasi pembelajaran dan lingkungan yang menjadi kajian, dan ketiga; memperluas kajian kependidikan dan non kependidikan pada sejumlah konteks terhadap kepastian dan tantangan masa depan (Benavides, F., Dumont, H., Istance, 2008). 
Terdapat penelitian terdahulu yang membahas mengenai menejemen pembelajaran bermutu pada kelas unggulan, sebagaimana dituliskan oleh (Bunai, 2018) mendeskripsikan tentang manajemen pembelajaran pada kelas unggulan di STAIN Pamekasan. Hasil penelitian menunjukan bahwa Pertama, para dosen dalam memberi kuliah pada kelas unggulan di STAIN Pamekasan telah melakukan persiapan sebelum memberi kuliah seperti: melihat silabi, membuat course outline, Satuan Acara Perkuliahan (SAP), kedua, para dosen mampu mengajar pada kelas unggulan di STAIN Pamekasan dengan baik, mulai membuka sampai menutup pelajaran, ketiga, para dosen mampu melaksanakan evaluasi pembelajaran pada kelas unggulan di STAIN Pamekasan dengan berbagai bentuk evaluasi dengan baik.

Penelitian lain yang dilakukan (Amalia Ratna Zakiah Wati \& Syunu Trihantoyo, 2020), penelitian ini mendeskripsikan dan menganalisis data tentang Strategi Pengelolaan Kelas Unggulan Dalam Meningkatkan Prestasi Belajar Siswa, faktor pendukung dan faktor penghambat dalam Strategi Pengelolaan Kelas Unggulan Dalam Meningkatkan Prestasi Belajar Siswa, dan Solusi dari hambatan yang terjadi dalam Strategi Pengelolaan Kelas Unggulan Dalam Meningkatkan Prestasi Belajar Siswa di SMPN 1 Turi Lamongan. Hasil penelitian Strategi pengelolaan kelas unggulan dalam meningkatkan prestasi belajar, maka diperlukan sebuah adanya strategi. SMPN 1 Turi Lamongan memiliki beberapa strategi untuk pengelolaan kelas unggulan dalam meningkatkan prestasi belajar siswa yaitu Membangun Kerjasama dengan Siswa dalam Pembelajaran, Menciptakan Iklim Pembelajaran yang Kondusif, Evaluasi Proses Belajar Mengajar.

MTsN 2 Model Bandar Lampung dan MTsN Model Talang Padang sebagai fokus lokasi penelitian, peneliti melihat ada upaya-upaya yang dilakukan lembaga pendidikan tersebut dengan membangun program kelas unggulan yang setidak-tidaknya program tersebut memiliki makna, ingin mengangkat citra madrasah menjadi madrasah unggul dalam bidang prestasi akademik maupun unggul dalam bidang prestasi non akademik.

Berdasarkan kajian pustaka, kebaruan penelitian ini terhadap penelitian bahwa bahwa pada penelitian yang lain belum ditemukan yang melakukan penelitian tentang implikasi pengelolaan pembelajaran bermutu pada kelas unggulan, tempat penelitian MTsN 2 Model Bandar Lampung dan MTsN Model Talang Padang. Fokus penelitian ini meliputi yaitu mengenai perencanaaan, pengorganisasian, pelaksanaan, evaluasi serta implikasi pembelajaran bermutu pada kelas unggulan di MTsN 2 Bandar Lampung dan di MTsN 2 Tanggamus. 


\section{METODE PENELITIAN}

Penelitian ini merupakan penelitian lapangan (field research), yaitu prosedur penelitian yang dilakukan langsung pada lokasi penelitian. Peneliti menentukan dua lokasi penelitian yakni, di MTsN 2 Bandar Lampung dan MTsN 2 Tanggamus karena memiliki karakteristik yang sama.

Sumber data dalam penelitian ini dapat dibedakan menjadi dua, yaitu data primer dan data sekunder. Menurut Lofland dalam (Arikunto, 2010) mengungkapkan bahwa sumber data primer dalam penelitian kualitatif adalah kata-kata atau tindakan, selebihnya adalah tambahan berupa dokumen dan lainlain. Sedangkan sumber data sekunder berupa dokumen yang relevan dengan fokus penelitian, seperti gambar, foto, catatan rapat atau tulisan-tulisan yang ada kaitannya dengan fokus penelitian.

Adapun analisis data pada penelitisn ini bersifat deskriptif analisis dengan menggunakan teknik analisis secara kualitatif. Tulisan ini bertujuan untuk menganalisis implikasi pengelolaan pembelajaran pada kelas unggulan. Penulis menggunakan pendekatan konsep (conceptual approach).

\section{HASIL DAN PEMBAHASAN}

\section{Pengelolaan Pembelajaran Bermutu}

\section{Pengelolaan Pembelajaran}

Pengelolaan pembelajaran dalam arti luas, dalam arti mencakup keseluruhan kegiatan bagaimana membelajarkan siswa mulai dari perencanaan pembelajaran sampai pada penilaian pembelajaran (Fauzi, 2020). Dalam arti luas, pengelolaan pembelajaran adalah serangkaian proses kegiatan mengelola bagaimana membelajarkan peserta didik dengan kegiatan perencanaan, pengorganisasian, pengarahan atau pengendalian, dan penilaian. Sedangkan pengelolaan pembelajaran dalam arti sempit diartikan sebagai kegiatan yang perlu dikelola pendidik selama terjadinya interaksi dengan peserta didik dalam pelaksanaan pembelajaran tujuan (Winardi, 1983).

Pengelolaan adalah proses penataan kegiatan yang akan dilaksanakan melalui fungsi-fungsi manajemen tentu gunanya sebagai tolak ukur untuk menentukan keberhasilan sebagai bentuk dari pencapaian tujuan bersama yang telah disepakati. (Fory A. Naway, 2016).

Hal ini didukung oleh (Supriyanto, 2008), pengelolaan adalah keterampilan untuk meramu komponen dan unsur-unsur yang terlibat dalam suatu sistem untuk mencapai hasil/tujuan yang direncanakan.

Strategi yang sudah disusun harus dipastikan keberhasilannya, oleh karena itu para manajemen akan selalu memantau dan mengevaluasi semua strategi yang diimplementasikan (Amalia Ratna Zakiah Wati \& Syunu Trihantoyo, 2020). 


\section{Tujuan Pengelolaan Pembelajaran}

Siswanto merumuskan tujuan manajemen sebagai sesuatu yang ingin direalisasikan, yang menggambarkan cakupan tertentu dan menyarankan pengarahan kepada usaha seorang manajer (guru). Berdasarkan rumusan tersebut, ada empat elemen dasar atau pokok yang dapat diambil sebagai tujuan, yaitu: 1) sesuatu yang ingin direalisasikan (goal), 2) cakupan (scopa); 3) ketepatan (defenitness); 4) pengarahan (direction) (Siswanto, 2005). Untuk itu, tujuan manajemen pembelajaran dalam rangka menentukan tujuan pembelajaran, ruang lingkup pembelajaran, waktu yang diperlukan serta diarahkan sesuai dengan mekanisme pembelajaran yang telah ditetapkan.

Tujuan utama pengelolaan pembelajaran adalah untuk menghemat waktu dan tenaga.Pengelolaan pembelajaran yang baik menolong menyediakan kondisi belajar yang menyenangkan dan prosedur yang efektif dalam menjalankan aktivitas secara ekonomis dan efisien (Risk, 1965). Pengeloaaan pembelajaran yang efektif merupakan prasyarat mutlak bagi terjadinya proses belajar mengajar yang efektif (Raka Joni, 2003).

Gregorio beranggapan bahwa kegagalan atau kesuksesan pendidikan anak didik di sekolah dapat juga ditentukan oleh bagaimana kelas itu dioorganisasikan dan dijalankan.(A.C.Gregorio, 1994) Menurut Levin and Nolan dalam Kambey: "Teachers who manage their cllassroms effectively enjoy teaching more and have greater confidence in their ability to effect student achievement" (para guru yang mengatur kelas mereka secara efektif akan lebih menikmati pengajaran dan lebih mempunyai kepercayaan untuk mempangaruhi prestasi siswa) (Daniel C. Kambey, 2003).

Suatu kondisi belajar siswa akan optimal jika pengajar mampu mengatur siswa dan sarana pembelajaran serta mengendalikannya dalam suasana ynag menyenangkan untuk mencapai tujuan pembelajaran.Keberhsilan pengelolaan pembelajaran juga didukung oleh hubungan interpersonal yang baik antara pengajar dengan pelajar dan antara siswa dengan siswa (Yuliani, 2002). Berdasarkan pada kajian teori, jelaslah bahwa tingkat tercapainya tujuan dari pengelolaan pembelajaran sangat ditentukan oleh guru (A.B. Syaiful Anwar, 2020).

\section{Konsep Kelas Unggulan}

Kelas Unggulan adalah kelas yang diikuti oleh sejumlah siswa yang unggul dalam tiga ranah penilaian dengan kecerdasan di atas rata-rata yang dikelompokkan secara khusus. Pengelompokan ini dimaksudkan untuk membina siswa dalam mengembangkan kecerdasan, kemampuan, keterampilan, dan potensinya seoptimal mungkin sehingga memilki pengetahuan, keterampilan, dan sikap yang terbaik sebagaimana semangat konsep wawasan keunggulan (Bafadal, 2006). 
Menurut (Surya, 2004), Prestasi belajar adalah perubahan perilaku individu. Individu akan memperoleh perilaku yang baru, menetap, fungsional, positif, disadari dan sebagainya. Perubahan perilaku sebagai hasil pembelajaran. Hal yang sama dikemukakan oleh (Purwanto, 2009) prestasi belajar adalah perubahan perilaku yang terjadi setelah mengikuti proses belajar mengajar sesuai dengan tujuan pendidikan (A. Syaiful Anwar et al., 2020).

Konsep pembelajaran pada kelas unggulan adalah pembelajaran yang dikembangkan berdasarkan standar input yang middle dengan menggunakan standar proses yang unggul (academic execellent based spritual learning) dan standar lulusan (output) yang unggul (Baryanto et al., 2019).

\section{Perencanaaan pembelajaran bermutu pada kelas unggulan di MTsN 2 Bandar Lampung dan MTsN 2 Tanggamus}

Desain perencanaan pembelajaran bermutu pada kelas unggulan di MTsN 2 Bandar Lampung maupun di MTsN 2 Tanggamus sama-sama diarahkan pada pola desain program pembelajaran melalui desain standar seleksi input, standar proses dan desain standar output. Pemberlakukan standar proses seleksi input dalam rangka memastikan dan menjamin program pembelajaran dapat berjalan sampai proses program pembinaannya. Adapun standar seleksi input dari dua madrasah yang menjadi penelitian menunjukkan ada perbedaan kriteria, yakni pada standar rata-rata rapot dan ada yang menggunakan psikotes dan ada yang tidak menggunakan psikotes. Perbedaan standar ini, berdasarkan temuan lapangan hanya disebabkan dasar pijakan masing-masing. Alasan yang menggunakan psikotes adalah berdasarkan pengalaman sebelumnya yang peserta didiknya mengalami tekanan-tekanan psikologis dalam mengikuti program kelas unggulan, sementara yang tidak menggunakan psikotes lebih didasarkan pada pola memberikan kesempatan kepada peserta didik untuk berkembang sesuai dengan kemampuannya. Sebagai gambaran, beberapa standar seleksi input adalah pertama; nilai rapot peserta didik rata-rata minimal 8 dan 7,5 dari tiga mata pelajaran, yakni Matematika, Bahasa dan IPA, kedua; lulus ujian tulis, ketiga; membaca al-Quran dan keempat; lulus uji tes psikologi. Proses seleksi ini dilakukan secara transparan dan akuntabel. Artinya, betul-betul murni akumulasi hasil tes dari beberapa jenis tes yang dijadikan bahan tes dalam proses seleksi.

Dalam pelaksanaan proses seleksi telah menjalankan apa yang disebut telah menjalankan prinsip-prinsip manajemen pada umumnya, seperti prinsip accountability dan transparan. Prinsip-prinsip ini diterapkan dalam rangka mengurangi resiko karena mengingat dari proses seleksi sebelumnya peserta didik ada yang berhenti di tengah jalan karena mereka kurang siap mengikuti program kelas unggulan. Dalam desain standar proses dikembangkan dengan desain kurikulum yang diperkaya dengan berpijak standar rancangan kurikulum yang disusun berdasarkan standar Nasional atau penyusunan dan pengembangan 
Kurikulum Tingkat Satuan Pendidikan (KTSP) mengacu pada Undang-Undang Nomor 20 tahun 2003 tentang Sistem Pendidikan Nasional. Pasal 36 Ayat (2) menegaskan bahwa kurikulum pada semua jenjang dan jenis pendidikan dikembangkan dengan prinsip diversifikasi sesuai dengan satuan pendidikan, potensi daerah, dan peserta didik (Undang-Undang No. 20 Tahun 2003 Tentang Sistem Pendidikan Nasional, n.d.).

Pengorganisasian pembelajaran bermutu pada kelas unggulan di MTsN 2 Bandar Lampung dan MTsN 2 Tanggamus

Pengorganisasian pembelajaran bermutu pada kelas unggulan di MTsN 2 Bandar Lampung dan di MTsN 2 Tanggamus diletakkan pada posisi strategis. Mulai dari pengorganisasian rumpun bidang studi atau mata pelajaran sampai pada pengorganisasian tugas dan peran guru-gurunya. Berdasarkan temuan lapangan kedua madrasah tersebut melakukan pengorganisasian beberapa komponen yang meliputi; kurikulum yang diperkaya, peran dan tugas guru, alokasi waktu dan sumber belajar.

\section{Pelaksanaan pembelajaran bermutu pada kelas unggulan di MTsN 2 Bandar Lampung dan di MTsN 2 Tanggamus}

Berdasarkan temuan lapangan menunjukkan bahwa pelaksanaan pembelajaran Bermutu, diimplementasikan dalam pola kurikulum yang diperkaya dengan kurikulum olimpiade, bahasa, dan agama, penataan kelas melalui moving kelas, guru yang terstandar, pengelolaan media berbasis IT dan full day school. Yang dimaksud kurikulum yang diperkaya adalah kurikulum yang dirancang dengan rumpun kurikulum olimpiade, bahasa, dan agama. Untuk MTsN 2 Bandar Lampung implementasi kurikulum dilaksanakan dengan program penajaman dan pembinaan, sementara MTsN 2 Tanggamus, pelaksanaan kurikulum dengan 2 program unggulan, dengan klasifikasi kelas pengayaan dan kelas remedial.

Model pembagian rombongan belajar dipetakan menjadi kelas kelompok belajar besar dengan pola paket kelas (big learning group class), dan ada kelas dengan pola kelompok belajar kecil (small learning group class). Kelas dengan pola kelompok belajar besar (big learning group class) dikembangkan di MTsN 2 Bandar Lampung sejak peserta didik masuk program kelas unggulan hingga selesai dengan kurikulum yang diseragamkan, sementara kelas dengan pola kelompok belajar kecil (small learning group class) dikembangkan di MTsN 2 Tanggamus dengan pola pembagian kelompok berdasarkan, minat dan bakat kecenderungan peserta didik, serta kemampuannya, sehingga jumlah kelompok belajar bervariasi. Ada yang berjumlah 7 orang dan ada yang berjumlah 15 orang seperti yang terjadi di MTsN 2 Tanggamus, sementara MTsN 2 Bandar Lampung menetapkan model paket kelas dan tidak memberlakukan seperti model yang dikembangkan MTsN 2 Tanggamus. Pola kelompok belajar ini lahir dari inisiasi 
para orang tua peserta didik yang menginginkan adanya pola pengelolaan pembelajaran bermutu kelas unggulan yang lebih baik dan progresif. Dengan lahirnya 2 tipe kelas yang dikembangkan pada kelas unggulan menunjukkan adanya pola desain pembelajaran kelas agar lebih efektif prosesnya dan lebih produktif hasilnya.

\section{Evaluasi Pembelajaran Bermutu Pada Kelas Unggulan di MTsN 2 Bandar Lampung dan MTsN 2 Tanggamus}

Fungsi evaluasi adalah untuk melihat sejauhmana tingkat ketercapaian dan keberhasilan program atau sebaliknya untuk mengetahui sejauhmana kelemahan, dan kegagalan program dalam hal ini pembelajaran bermutu. Evaluasi pembelajaran bermutu pada kelas unggulan di MTsN 2 Bandar Lampung dan di MTsN 2 Tanggamus, menerapkan teknik evaluasi dengan tes dan non tes, try out dan mastery learning. Teknik tes meliputi tugas terstruktur, quis, dan tugas mandiri, drill, dan ujian akhir semester sedangkan teknik non tes meliputi pengamatan dan tanya jawab. Teknik try out dilakukan pada saat menjelang olimpiade dan Ujian Nasional. Pelaksanaan evaluasi dalam bentuk quis bilamana guru bermaksud melihat capaian materi tertentu, sehingga guru dapat melanjutkan materi berikutnya. Berdasarkan temuan lapangan, quis ini dilaksanakan oleh beberapa guru saja misalnya dalam bidang studi matematika, biologi, bahasa Inggris, fisika dan dilaksanakan 1 (satu) atau bahkan dapat 2 (dua) kali seminggu. Jenis evaluasi lain yang dilakukan oleh guru di dua MTsN tersebut adalah evaluasi latihan soal (drill); alat evaluasi ini diberikan kepada peserta didik setiap setelah menerima materi pelajaran. Bentuk evaluasi ini bermanfaat dalam memberikan informasi tentang sejauhmana materi yang dipelajari khususnya materi-materi pelajaran olimpiade dapat dikuasai peserta didik. Manfaat lain, guru juga dapat mengetahui sejauhmana target dan tujuan pembelajaran sudah dicapai atau belum dan bentuk evaluasi ini secara langsung dapat diketahui baik oleh peserta didik maupun guru.

\section{Implikasi Pengelolaan Pembelajaran Pada Kelas Unggulan di MTsN 2 Bandar Lampung dan MTsN Tanggamus}

Berdasarkan temuan konstruksi pembelajaran bermutu pada kelas unggulan adalah pembelajaran yang dikembangkan berdasarkan imput yang midle dengan menggunakan proses yang unggul (academic execellent based spritual learning) telah melahirkan lulusan (output) yang unggul. Namun demikian, adanya pembelajaran bermutu tersebut tidak serta merta dapat berjalan dengan baik manakala tidak ikuti dengan pengelolaan yang benar. Yaitu berawal dari perencanaan pembelajaran yang didesain dengan kurikulum yang diperkaya (enriched curriculum) olimpiade sains, bahasa, agama melalui desain standar proses academic execellent berbasis spritual learning terhadap input yang midle dan didesain dengan standar output yang unggul. Kemudian, penataan dan pengelolaan 
pembelajaran yang bermutu pada kelas unggulan telah dibungkus melalui kurikulum yang diperkaya (sain, bahasa, dan agama), SDM yang tepat, efisiensi waktu, pembelajaran berbasis IT, dan dukungan orang tua. Sementara pelaksanaan pembelajaran bermutu telah dikemas melalui integrasi antara akademic execellent dengan spritual learning, penataan kelas melalui moving class, pembelajaran berbasis IT, program penajaman, pengayaan, remidial dan pembinaan, serta dilaksanakan dengan sistem ful day school. Adapun evaluasi pembelajaran yang unggul pada kelas unggulan telah menerapkan teknik evaluasi yang tidak hanya mengedepankan teknik evaluasi sumatif dan formatif melainkan teknik mastery learning dan high competition. Berdasarkan pembelajaran bermutu dengan memperhatikan pengelolaan yang benar seperti di atas, maka implikasi pengelolaan pembelajaran bermutu pada kelas unggulan di MTsN 2 Bandar Lampung dan MTsN 2 Tanggamus telah memberikan dampak pada sistem pembelajaran yang integratif semakin efektif, standar kualifikasi guru semakin baik, dan reputasi madrasah semakin meningkat.

Berdasarkan analisis terhadap berbagai temuan dan kerangka teoritik yang digunakan, penelitian ini menemukan konsep baru sebagai temuan akademik yaitu model pembelajaran pembelajaran bermutu pada kelas unggulan adalah model pengelolaan pembelajaran yang dikembangkan melalui kurikulum yang diperkaya (enriched curriculum) dengan standar proses academic axecellent berbasis spiritual learning terhadap input yang midle sehingga dapat melahirkan lulusan yang berkualitas.

\section{KESIMPULAN}

Pembelajaran pada kelas unggulan di MTsN 2 Model Bandar Lampung dan MTsN model Talang Padang didesain melalui perencanaan, pengorganisasian, pelaksanaan, dan evaluasi terhadap input yang middle melalui proses yang unggul dengan dilandasi oleh semangat spritual learning yang dapat memperkuat sistem pembelajaran. Implikasi pengelolaan pembelajaran bermutu pada kelas unggulan di MTsN 2 Bandar Lampung dan di MTsN 2 Tanggamus telah yaitu terbentuknya sistem pembelajaran yang integratif dan Terbentuknya standarisasi guru.

\section{REFERENSI}

A.C.Gregorio. (1994). Principle and Methods of Theaching. RP Gercia.

Agus Maimun dan Agus Zaenal Fitri. (2010). Madrasah Unggulan: Lembaga Pendidikan Alternatif di Era Kompeteitif. UIN Press.

Ahyar. (2018). Peningkatan Kinerja Madrasah Melalui Pendekatan Kultur. Jurnal Taskif Fakultas Tarbiyah, Vol. 11(No.1), 83. 
Amalia Ratna Zakiah Wati \& Syunu Trihantoyo. (2020). Strategi Pengelolaan Kelas Unggulan Dalam Meningkatkan Prestasi Belajar Siswa. Jurnal Dinamika Manajemen Pendidikan (JDMP), Vol 5(No 1), 46-57. https://doi.org/10.26740/jdmp.v5n1.p46-57

Arikunto. (2010). Suharsimi Arikunto.pdf. In Prosedur Penelitian Suatu Pendekatan Praktik-Revisi ke X.

Bafadal, I. (2006). Manajemen Peningkatan Mutu Sekolah Dasar dari Sentralisasi Menuju Desentralisasi. Bumi Aksara.

Baryanto, B., Bahri, S., \& Fathurrochman, I. (2019). Islamic Habituation in Growing Students , Social Behavior. 2, 1980-1985. https://doi.org/10.35940/ijeat.B2948.129219.

Benavides, F., Dumont, H., Istance, D. (2008). The Search for Innovative Learning Environments (Innovating to Learn, Learning to Innovate). OECD.

Bunai, B. (2018). Manajemen Pembelajaran Pada Kelas Unggulan Di Stain Pamekasan. Islamuna, Vol. 5(No. 2).

Daniel C. Kambey. (2003). Manajemen Kelas, (p. 2). Materi Pada Diklat Widyaiswara Berjenjang Tingkat Pertama di Balai Diklat Keagamaan.

Fauzi, F. (2020). , Implikasi Pengelolaan Kelas Bilingual Terhadap Peningkatan Mutu Siswa Sekolah Menengah Pertama MTs.Hidayatul Muttallimin Sidoarjo. Darajat: Jurnal PAI, Vol. 3(No. 1).

Fory A. Naway. (2016). Strategi Pengelolaan Pembelajaran. Ideas Publishing.

Harun, F. (2016). Membangun Citra Madrasah Melalui Program Kelas Unggulan Di Mtsn 2 Bandar Lampung. EDUKASI: Jurnal Penelitian Pendidikan Agama Dan Keagamaan, Vol. 14(No 3).

Ondi Saondi dan Aris Suherman. (2010). Etika Profesi Keguruan (Cet 1). Refika Aditama.

Purwanto, N. (2009). Ilmu Pendidikan Teori dan Praktis. PT. Remaja Rosdakarya.

Raka Joni. (2003). Pengelolaan Pembelajaran. P3G.

Risk, T. (1965). Principles and Practie Of teaching in Secendary Schools. Eurasia Pub.House.

Siswanto. (2005). Pengantar Manajemen. Bumi Aksara.

Supriyanto, M. (2008). Teknologi Informasi Perpustakaan. Kanisius.

Surya, M. (2004). Psikologi Pembelajaran dan Pengajaran. Pustaka Bani Quraisy. 
280 | Tadbir: Jurnal Studi Manajemen Pendidikan, Vol. 4, No. 2, 2020

Syaiful Anwar, A. B. (2020). Strategy for competitiveness of higher education use factor internal/ External strategic and matrix space analysis. Universal Journal of Educational Research, 8(7), 2749-2757. https://doi.org/10.13189/ujer.2020.080701

Syaiful Anwar, A., Febriawati, H., Alfansi, L., \& Hadi, E. D. (2020). Analysis the role of management for achieving of public health coverage programs at public helath care in Bengkulu. Indian Journal of Forensic Medicine and Toxicology, 14(3), 2185-2190.

Undang-Undang No. 20 Tahun 2003 tentang Sistem Pendidikan Nasional.

Winardi. (1983). Asas-Asas Manajemen. Penerbit Alumni.

Yuliani, E. S. dan. (2002). Kemampuan Dasar Mengajar. Pusat Penerbitan Universitas Terbuka. 